\title{
SUSTAINABLE STEELWORKS IN POLISH MARKET
}

\author{
BOŻENA GAJDZIK ${ }^{1}$ \\ Silesian University of Technology (Poland)
}

\begin{abstract}
In the paper market situation of domestic steelworks during restructuring process was characterized. In the analysis the key elements of enterprises competitiveness were presented. Moreover the organizational changes in the steelworks plants and their influence on the sustainability were presented too. In the paper two kinds of restructuring were described: repair and development.

KEYWORDS: sustainable steelworks, restructuring process, improvement, sustainability.
\end{abstract}

JEL CODES: Q010, Q150

\section{Introduction}

After 1989 new challenges appeared for the functioning of the enterprises in Poland. Transformations happening in all walks of social and economical lives influenced the introduction of changes in enterprises, which resulted from the necessity to adjust them to the requirements of the market economy. Enterprises in many sectors of economy were obliged to adjust to new conditions, first of all, in need of survival, and next in order to develop and build sustainability. During the analysis of the functioning of enterprises in Poland two forms of restructuring processes were noticed. First form - repair restructuring were realised in the initial period of economical changes. The aim of the restructuring programs at that time was the survival of the steelworks plants. In the period (after 1990) steelworks plants realized first environmental investments. Second form - development programs (first years of new century until the global economic crisis) which helped them to be sustainable steelworks plant in all of their activities.

The aim of this paper is to discuss the most important areas of introduced changes in the functioning of steelworks, especially in the area of it sustainability. The key problem of the paper is meaning the sustainability in steelworks. How components of its activities create sustainable business. This publication is a result of observations of changes occurring in metallurgy sector in Poland.

Object of research - restructuring process in enterprises of the metallurgical sector.

The purpose of research: presentation of the way from restructuring process to sustainable business for example metallurgical enterprises. Foundation: sustainable enterprise is the result of restructuring process. Metallurgical enterprises have to realize two forms of restructuring:

- repairing programs;

- development programs.

The tasks of the article are to try to refer to the following issues:

- Repair restructuring process in steelworks - the first step to sustainability.

Bożena Gajdzik (Ph.D) - The Silesian University of Technology, Materials Science and Metallurgy Faculty, Management of Computer Science Department. Scientific interest: management and economy.

E-mail: Bozena.Gajdzik@polsl.pl

Tel.: 326034326. 
- Development restructuring process in steelworks - the second step to sustainability.

- Features of sustainable steelworks.

The method: the analysis of scientific articles, statistical materials and own research.

\section{Repair restructuring process in steelworks - the first step to sustainability}

The term ,restructuring” was for many years identified with repairing of the enterprise functioning. The meaning of the radical changes and necessity of their introduction were underlined. They were a result of critical signals most often connected with lack of financial fluidity of the enterprises (Malara, 2001: 16; Nalepka, 2008:19; Durlik, 1998: 48; Bowman, Singh, 1993: 6). The radical changes are features of repair restructuring process. New definitions of restructuring appeared together with the introduction of the economy rules which were open to the demands of globalisation. In those, the need of constant reconstructions, modernisations, improvements and updates in the enterprise were exposed and underlined. It is also important to point at the fact that the aim of restructuring is the achievement of the highest effectiveness of enterprise functioning (Porada-Rochon, 2009: 69; Malara, 2001: 36). The highest effectiveness is the key element of development restructuring process. Moreover development restructuring process is connected with realisation of strategy of value increase of an enterprise (Hurry, 1993: 16). The restructuring process very often causes changes in enterprise strategy. There is dependence between strategy, environment and restructuring process. Enterprise environment influence both strategy and restructuring process (Chandler, 1962: 14-16). Modern enterprise realize sustainable strategy according to international program. The strategic elements of changes in enterprises during restructuring process cause that enterprises change their values (Thierry, 1995: 14). In sustainable concept the new values are called sustainable value. In sustainability enterprises build sustainable value in long period. The first step to building new enterprise value in metallurgical sector in Poland was repair restructuring. The sustainable development of enterprises must go before urgent changes (Singh, 1993: 148-150). Such changes were realized in restructuring programs in many enterprises of different sectors of industry in 90. XX century. Repair programs in enterprises in Easter and Central Europe were results of economy transformation. In outer countries of Europe and in US changes in enterprises was called reengineering (Manganelli, Klein, 1998: 21-26). In the paper only repair programs in Polish metallurgical sector was described.

Repair actions in Polish metallurgy sector began in 1992 with government program of metallurgy restructuring. The most important event then was closing the privatization transaction of Polskie Huty Stali. Corporation, in the end of 2003, was taken over by British LNM Group, which was later bought by Indian ISPAT later named Mittal Steel Company. In June 2006 concern Mittal merged with Arcelor. Nowadays ArcelorMittal Poland is the largest steel producer in Poland, concentrating more than 70 percent of Polish steel production capacity. The Group employs over 12 thousand people. Six steel pants create the enterprise ArcelorMittal Poland. They are located in five cities: Kraków, Dąbrowa Górnicza, Sosnowiec, Świętochłowice and Chorzów. After ten years work, modernization, investments worth over PLN 4 billion and transfer of the world's best practices - all in order to give the Polish steel industry a new face. In repair restructuring process five strategic investment projects were realized in ArcelorMittal Poland: 1) The new Hot Strip Mill in Kraków; 2) the new Continuous Caster in Dąbrowa Górnicza; 3) the new Colour Coating Line in Świętochłowice; 4) the modernized Wire Rod Mill in Sosnowiec; 5) the modernization of Blast Furnance in Dąbrowa Górnicza. Realized investments were first step to sustainable business (Gajdzik, 2012: 54). According to definition of sustainable development the environmental investments have important place in the concept (Piontek, 2002: 10).

Very important palace in repair restructuring process had employment reduction. The employment in Polish steelworks was reduced from 147000 people in 1990 to 25000 in 2010 . The effect of the employment reduction is the improvement of the work efficiency. Before restructuring, one worker equalled about 
130 tonnes of steel a year and now it is 500 tonnes a year (the average in the European Union is around 600 tonnes of steel a year per worker) (Gajdzik, 2012: 58).

The next change was production reduction. In the $80 \mathrm{~s}$ of $20^{\text {th }}$ century the metallurgy sector on Polish market produced up to 19 million tonnes of crude steel a year and in 2010 a sum of 8 million tonnes of steel was reached. Reduction of the production was caused by market demand, particularly in building sector (residential and infrastructural) as well as automotive, machinery builder, home appliances and metals industries. Production of crude steel was reduced and the production of manufactured products increased. In the area of use of metallurgical products an increase of sales in flat products and pipes was noticed, which means products of high added value. In order to increase sales of metallurgical products the production and distribution enterprises created specialised service centres offering the selection of products adjusted to individual expectations of customers (Gajdzik, 2011: 945-952).

The result of the repair programs in the enterprises was a new subject structure of the metallurgical market. Until 2005 the ownership changes took place in most Polish steelworks which caused the creation of new metallurgical enterprises, often with new names. Most steelworks changed their legal status and on the basis of the possessions of the steelworks new production and service companies were created. Four metallurgical enterprises: ArcelorMittal Poland, CMC Zawiercie, Huta Ostrowiec and Huta Częstochowa (ISD Donbas) manufacture together over $90 \%$ of Polish steel. Owner of the enterprises is foreign capital (Gajdzik, 2011: 945-952).

To sum up, the basis for repair restructuring in Polish metallurgical sector were the activities on the operational and resources level (Ingram, 2002: 25). The downsizing type activities dominated, based on reduction of employment, reduction of the production size and the sales decrease. In the period of changes steelworks had to spend significant sums of money for modernisation of the production process in order to prepare the production for the concept of sustainable development. The basic assumption here was the reduction of negative (often uncontrolled influence of steelworks on the environment).

The restructuring process of enterprises in metallurgical sector was realized in all countries in Easter and Central Europe during economy changes. For example the new owner of Steelworks Plant Koszyce is US Steel, Nova Steelworks - Mittal Steel, Vitkovice Steel - now Evraz Group, new owner of Dunaferr is ISD Donbas. Steelworks plants in Czech Republic produced 11 million tonnes of crude steel before restructuring, now 8.1 million tonnes. Employment in steelwork plants before restructuring process 94000 people, now 24000 people. In Rumanian steelworks plants was produced 15 million tonnes of crude steel, after restructuring steelworks produce 8 million tonnes. Employment in Rumania was 123000 people, now about 50000 people (on the base of EU Report about Restructuring in Metallurgical Sector http://eur-lex.europa. eu/LexUriServ).

2. Development restructuring process in steelworks - the second step to sustainability

A process of the development restructuring started in 2005 but first symptoms of changes were observed in 2004. Metallurgy branch activated as a result of huge demand for steel and metallurgical products on Chinese market. From 2004 the metallurgy sector in Poland started to earn net profit. The year 2005 was also very important for development restructuring. This was a year of completion of most ownership changes. In 2005 , for the first time since the 90 s of $20^{\text {th }}$ century, an increase of the employed workers in the metallurgy sector has been observed. Good financial situation of the steelworks resulted in the increase of the expenses for investments. In 2006 the Polish metallurgy spent 1 billion euro on environmental investments (Gajdzik, 2011: 945-952). Strategic investments of ArcelorMittal Poland, 2004-2008 were presented in table 1. 
Table 1. Strategic investments of Arcelor Mittal Poland, 2004-2011

\begin{tabular}{|c|c|c|c|}
\hline Investment & Investment time & Investment cost & Effects/production capacity \\
\hline Hot strip mill in Kraków & $\begin{array}{l}\text { July } 2005-\text { June } 28^{\text {th }} \text {, } \\
2007\end{array}$ & USD $400 \mathrm{~m}$ & $\begin{array}{l}\text { Production capacity } 2.4 \text { million } \\
\text { tonnes per year }\end{array}$ \\
\hline $\begin{array}{l}\text { Continuous casting } \\
\text { line no. } 3 \text { in Dąbrowa } \\
\text { Górnicza }\end{array}$ & $\begin{array}{l}\text { December } 2005- \\
\text { December 29, } 2006\end{array}$ & USD $141.6 \mathrm{~m}$ & $\begin{array}{l}\text { CCM machine is environmentally } \\
\text { friendly }\end{array}$ \\
\hline $\begin{array}{l}\text { Modernization of wire } \\
\text { rod mill in Sosnowiec }\end{array}$ & November 2006 & USD $42.18 \mathrm{~m}$ & $\begin{array}{l}\text { Products of highest quality. The } \\
\text { capacity of the mill comes to } \\
750000 \text { tonnes a year. The modern } \\
\text { efficient furnace produces } 160 \\
\text { tonnes per hour }\end{array}$ \\
\hline $\begin{array}{l}\text { Colour coating line in } \\
\text { Świętochłowice }\end{array}$ & 2006 & USD $33.42 \mathrm{~m}$ & $\begin{array}{l}\text { Target capacity of the line amounts } \\
\text { to } 200000 \text { tonnes a year }\end{array}$ \\
\hline $\begin{array}{l}\text { A full overhaul and } \\
\text { modernization of blast } \\
\text { furnace no. } 2 \text { in Dąbrowa } \\
\text { Górnicza }\end{array}$ & September 2006 & USD $84 \mathrm{M}$ & $\begin{array}{l}\text { Capacity of the furnaces was } \\
\text { improved from } 6000 \text { do } 7000 \\
\text { tonnes of the hot metal a day }\end{array}$ \\
\hline \multirow{2}{*}{$\begin{array}{l}\text { Modernization and } \\
\text { construction of new coke } \\
\text { batteries at Zdzieszowice } \\
\text { Coke Plant }\end{array}$} & $\begin{array}{l}\text { A new coke battery } \\
\text { no. } 11 \text { was launched in } \\
\text { March } 2006\end{array}$ & USD $60 \mathrm{M}$ & The highest capacity \\
\hline & $\begin{array}{l}\text { A new battery no. } 12- \\
\text { came into use in April } \\
2009\end{array}$ & USD $63 \mathrm{M}$ & The highest capacity \\
\hline $\begin{array}{l}\text { Modernization of cold } \\
\text { rolling mill in Kraków }\end{array}$ & November 2009 & USD $33 \mathrm{M}$ & $\begin{array}{l}\text { Effects: automotive operations, the } \\
\text { highest quality parameters of rolled } \\
\text { products }\end{array}$ \\
\hline $\begin{array}{l}\text { System for dedusting at } \\
\text { the process line for BF } 2 \\
\text { in Dąbrowa Górnicza }\end{array}$ & 2006 & PLN 30 million & $\begin{array}{l}\text { The investment allowed to reduce } \\
\text { dust emission by } 40 \% \text { since } 2004\end{array}$ \\
\hline $\begin{array}{l}\text { Construction of the PCI } \\
\text { installation for blast } \\
\text { furnaces no. } 3 \text { and } 5 \text { in } \\
\text { Kraków }\end{array}$ & Completed in 2007 & - & $\begin{array}{l}\text { Investment allowed to replace } \\
\text { coke used in the BF process with } \\
\text { pulverized coal and in turn to } \\
\text { reduce emission of dusts, sulphur } \\
\text { dioxide, } \mathrm{NO}_{x} \text {, hydrocarbons and } \\
\text { carbon monoxide at the coke plant }\end{array}$ \\
\hline $\begin{array}{l}\text { Modernization of the } \\
\text { Chemical Department at } \\
\text { the Kraków Coke Plant }\end{array}$ & Completed in 2011 & PLN 100 million & $\begin{array}{l}\text { Investment allowed to eliminate } \\
\text { dangerous substances like arsenic } \\
\text { oxide or sulphurous acid from } \\
\text { process }\end{array}$ \\
\hline $\begin{array}{l}\text { Closing circuits of water } \\
\text { in the Batory Unit }\end{array}$ & 2011 & $\begin{array}{l}\text { PLN } 4.5 \text { million and } \\
\text { was co-financed by } \\
\text { National Found for } \\
\text { Environmental Protection } \\
\text { and Water Management } \\
\text { and European Regional } \\
\text { Development Fund }\end{array}$ & $\begin{array}{l}1000000 \mathrm{~m}^{3} \text { of water per year } \\
\text { have been saved as a result of an } \\
\text { investment in closing water circuits } \\
\text { in ArcelorMittal Poland Batory } \\
\text { Unit }\end{array}$ \\
\hline $\begin{array}{l}\text { Modernization Hot } \\
\text { Roiling Mill in Kraków }\end{array}$ & - & 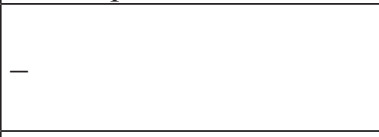 & $\begin{array}{l}\text { The energy consumption in the } \\
\text { Kraków Hot Roiling Mill decreased } \\
\text { by } 50 \%\end{array}$ \\
\hline $\begin{array}{l}\text { Soundproofing noise } \\
\text { sources }\end{array}$ & systematically & $\begin{array}{l}\text { Kraków PLN } 7850000 \\
\text { Świetochłowice PLN } \\
850000 \\
\text { Królewska PLN } 204000\end{array}$ & Reduction of noise \\
\hline
\end{tabular}




\begin{tabular}{|l|l|l|l|}
\hline \multicolumn{1}{|c|}{ Investment } & \multicolumn{1}{c|}{ Investment time } & \multicolumn{1}{c|}{ Investment cost } & \multicolumn{1}{c|}{ Effects/production capacity } \\
\hline $\begin{array}{l}\text { Installation of a new } \\
\text { strip cooling line in } \\
\text { Swiętochłowice }\end{array}$ & - & PLN 1 million & Quality of sewage \\
\hline A sewage treatment plant & 2011 & $\begin{array}{l}\text { Dąbrowa Górnicza PLN 2 } \\
\text { million } \\
\text { Kraków PLN 40 million }\end{array}$ & Quality of sewage \\
\hline
\end{tabular}

Source: Report AMP, 2010: 18-29.

Environmental protection is a strategic goal of the company ArcelorMittal Poland provided for in the Integrated Management System Policy compliant with ISO 14001:2004. The Environmental Management System according to standard ISO 14001:2004 is integrated with Quality Management System (ISO 9001:2008) and Safety and Health Management System (PN-N 18001:2004). ArcelorMittal Poland promotes its activities by $3 \mathrm{xS}$ which stand for Safe, Sustainable, Steel and 4xC which are Cash, Customer, Cost, Communication. The basic areas of strategic competitive advantage of the enterprise are taking care of the customer, the environment and work safety.

Apart from the investments concerning the expansion of the real estates, the companies completed also some organisational and management innovations. An important aspect of changes was also the introduction of the ideas of Kaizen philosophy, allowing for constant improvement of the functioning in an enterprise.

People managed by clear criteria, treated justly and respectably, who perceive similarly relations between organisation and surrounding, certainly will make effort to repay with the same. Employee's honesty towards employer, loyalty towards coworkers, legibility and maximum objectivity in evaluating employee, in the process of bonificating him/her, also punishing if needed, are the leading attributes of ethical organisation. Via taking social responsibility challenges company improves its standards of behaviour towards stakeholders (employees, contactors, and customers), same time avoiding costs of 'bad partnership'. These changes influence shaping the organisational culture of the company based on trust, responsibility and clearness for all interested parties (Wziątek-Staśko, 2011: 73). The good way to create such culture is diversity management- the highest human resources development level. It is a task which requires special competences and deep analysis to notice, understand and apply solutions that seriously tackle employee diversity in an organisation. It will be harmful and not beneficial to an organisation if the process lacks necessary professional approach (Wziątek-Staśko, 2012: 149).

The health and safety management system is crucial in the management of a steelworks plant after repair restructuring process. It affects both economic (work efficiency growth) and social factors (employees satisfaction). A safe workplace (with a low accident rate) contributes to profit growth and competitiveness of a company. An important objective of health and safety management is to minimize the number of accidents and prevent them by identifying and eliminating the most dangerous spots on the site. The reduction of the accident rate in ArcelorMittal Poland is to be accomplished through the following actions: a comprehensive involvement of workers, worker observation and reporting workers' behaviour, collection of data on health and safety at work and their use in the removal of barriers and threats, implementation of health and safety procedures and system, regular audits, implementation of annual action plans for the improvement of safety in individual production plants. Together with the health and safety strategy in the plants there are not only annual working conditions improvement plans but also programmes to raise workers' awareness. As health and safety are also a marketing tool for the company the following slogan has been adopted: We build a safe organization. We are not as strong as our products and therefore health and safety issues are our priority. Journey to zero accidents in work Gajdzik, Borowik, 2008: 66-70). In 2003 there were 184 accidents in four steelworks plants of the company. In 2005 there were 99 accidents. In 2006 there were 119 accidents and in 2007 there were 74 accidents, now only 18 accidents (Fig. 1). 


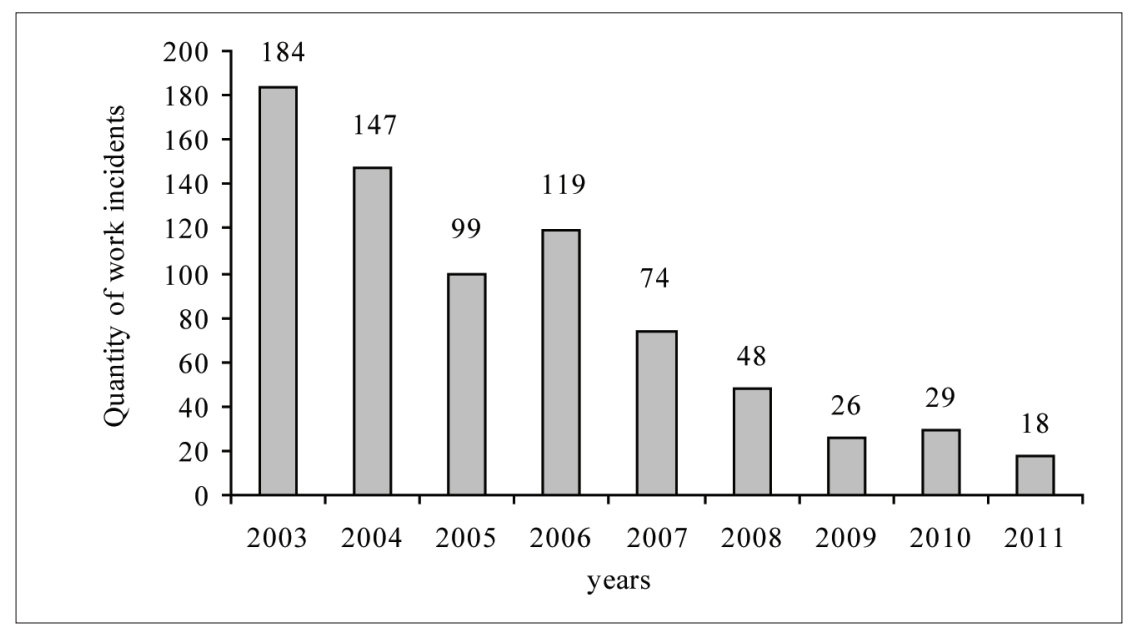

Figure 1. Work accidents in ArcelorMittal Poland in 2003-2011 (accidents with a break) Source: Report safety and Health AMP, 2003-2011.

Other example tasks implemented by the enterprises within development restructuring were: diversification of products (going beyond the previous range of business activity of the enterprise), expansion of production assortment (new products with higher added value), technological innovations which help reach the world class standards of production (World Class Manufacturing), implementation of new work organisation methods and management techniques, entering the new sales markets, extended marketing activities based on the knowledge of the brand, combining the capital groups (takeovers, mergers), vertical and horizontal consolidations. Efficient development restructuring allows the enterprises to compete on the world markets and to increase their market value.

In conclusion, development restructuring process in steelworks plants is characterised by high competence level (strategic areas are quality, environment and work safety), development of human resources (reduction of employment and raising the qualifications of the employees), creation of innovative solutions in the field of production and specialised services, openness to the relationships with the surrounding, and what is crucial, accumulation of knowledge in the area of management and organisation.

\section{Features of sustainable steelworks}

Sustainable development is conditioned by the ability of the enterprise to manage in the dynamic surrounding. Models of sustainable development which are based on exposing only the financial ecological investments quickly grow old and make way for models in which the non-financial aspects are exposed together with ecological-economical calculation as integrated measuring instrument of economic, ecological and social efficiency (Nowak, 2002: 50). Modern concept of sustainable development of steelworks is based on initiation of tasks which limit the negative effects of business activities towards the environment and society; it means also being a responsible enterprise towards various groups of stakeholders (workers, customers, counterparties). Sustainable development requires the completion of many aims. These are: economic aims connected with business activity, ecological aims in the form of limiting the negative influence of the business on the natural environment, social aims based on co-operation of business with social life and the aims connected with work safety and protection of health of the employees. Modern steelworks have learned the "good job" by investing in people, the environment and social relationships. Steelworks are aware of the fact that they are a part of complex surrounding and that they do not exist and function alone in this complex surrounding (Gajdzik, 2008: 109-119). 
On the basis of the sustainable development concept, new paradigms of business activities of enterprises appear, particularly the new modern mega-paradigm which is sustainability (...) as a determinant of modernity in functioning of the enterprises and their vitality (life energy). Sustainability is "the ability of the enterprise to learn continuously, to adapt and develop, to revitalise and reconstruct and the ability for re-orientation in order to keep the long-lasting and distinguished position on the market by offering the superior value to the purchaser today and in the future, by organic changeability which constitutes the business models and results from creating new possibilities and aims and meeting their demands by balancing the interests of various groups" (Grudzewski and others, 2010: 26). Sustainability must be based on the openness to of the enterprise to changes. The concept of sustainability, when efficiently applied in the enterprise, provides the "successful existence" in the new reality (Grudzewski and others, 2010: 29). The main ideas of sustainability are all the "re" concepts: restructuring, re-vitalising, re-organisation, reconstruction, and reorientation) which are integral part of the changes of the enterprises in dynamic surrounding. There is conformity of aims between sustainability and restructuring. In both of them the enterprise strives at reviving the business and achieving the possibility to continue business activity. In our deliberation so far, restructuring was divided into repair restructuring and development restructuring. In context of sustainability, repair restructuring is the basis for development restructuring the result of which is sustainable business. If an enterprise is characterised by sustainability then it may be called a sustainable enterprise and its business activities may be called sustainable business (Grudzewski, 2010: 29).

Taking into account the range of tasks undertaken by the enterprise, in order to reach sustainability, there are three levels of the maturity of the enterprise:

1. Low maturity level is when in business practice there are not enough proofs of ecological effects of business activity of the enterprise, investments are completed in a limited range and many planned investments remain investments only on paper.

2. Medium maturity level is a situation when the effects of completed ecological investments are visible, additionally the enterprise starts to improve the chosen areas of business activity, the company is customer-oriented but the reference of aims to the needs of other groups of stakeholders is small.

3. High maturity level occurs when the improvement tasks are applied in all areas of functioning in the enterprise, there are innovative activities, the enterprise invests a lot in process, product and technological innovations and the aims of the enterprise are oriented on all groups of stakeholders.

On the third (highest) level of sustainability development, the enterprise created a new value which is called sustainable value (Grudzewski and others, 2010: 157), and which is the result of the completion of the whole set of integrated aims. Sustainable value of the enterprise is the result of a synergy of activities connected with raising the level of many of its attributes. Those attributes may concern the assets of the enterprise (purchase and installation of new tangible assets, new or modernised technologies, purchase of patents and licenses), their financial situation (profit of the enterprise, increase of dividend for shareholders), added value (difference between the value of the manufactured goods and the costs of their manufacturing), the image of the brand (tradition of the brand on the market, the popularity of the brand among customers), relationship of the enterprise with stakeholders (network connections, loyalty programs for customers, activities of the company for the sake of the local communities, for example by volunteer activities of the employees) and other activities which work for the sake of the company - goodwill (Kamela-Sowińska, 1996: 32; Michalski, 2001: 26). As it is underlined by A. Rappaport (1999: 11) the main sources of value creation in the enterprise are innovations, they are the core, and in case of sustainable value these are ecological innovations which aim at reducing the negative influence of the business on the natural environment. On the basis of such assumption a new concept of "valuable innovations" or "innovations of value" appeared (Kim, Mauborgne, 2004: 172-180), which are such innovations which bring effects for the environment. For the companies to be able to start creating innovations of value, they need to have such resources first which are the sources for value generation. Therefore, the enterprise must conduct or must have conducted the restructuring process. The consequence of sustainable development of the enterprise is the growth of importance of connecting 
various categories of enterprise value assessment. The measurable aspect of an efficient company is reaching own economical goals as well as maintaining the beneficial relationship with the surrounding.

Generally speaking, a sustainable company is one characterised by the following qualities:

- has fixed sustainable strategy of development, which is implemented in a consistent way;

- integrates its business aims with other aims, the completion of which is a chance to exist in dynamic surrounding;

- is an innovative company in terms of technology, production, organisation and management;

- is an intelligent company - puts emphasis on development of intellectual capital, manages the knowledge, has specified tasks on all levels of organisation;

- treats its manufacturing potential as fluent and open, backs up new ideas which are often initiated by employees of the lowest rank in the organisation;

- creates new value which requires continuous changes in operational systems and strategies of acting transfer of technologies, purchase of patents, licenses, development of $\mathrm{B}+\mathrm{R}$ section, development of knowledge of employees;

- is effective learning oriented, that is learning connected with searching, application and spreading the knowledge in order to achieve the status of sustainable enterprise.

\section{Conclusions}

The changes in metallurgical sector observed recently allow for a statement that steelworks in Poland are sustainable. Ecological investments and improvement of various areas of functioning will make the completion of the sustainable development model possible. New enterprises are going to be created, the socalled sustainable ones, in which besides the hard factors (manufacturing technology) the competences of employees and pro-social and pro-ecological play an important role. In the end, it is worth to mention the assumptions of sustainability of metallurgical enterprise Arcelor Mittal Poland, which was treated as case study for this publication: Our obligation towards the world around us goes beyond the results of the company; it comprises the people in who we invest, the communities we support and the world in which we function. It is a long-term concept which is the basic element of our business philosophy (ArcelorMittal, "Polska Stal", nr 31/2007).

General conclusion which can be drawn on the basis of observation of changes occurring in metallurgical sector is the following: thanks to restructuring the steelworks prepared themselves for sustainability, modernisation of manufacturing processes took place together with increase of efficiency, increase of work safety and increase of product quality. Changes implemented in the steelworks may be considered key changes for sustainable development because only innovative enterprises can build up new sustainable value in the concept of which both the needs of internal business and the needs and expectations of customers and other groups of stakeholders are equally important.

\section{References}

Bowman, E. H., Singh, H. (1993). Corporate Restructuring. Reconfiguring the Firm. Strategic Management Journal, Vol. 14, Special Issue, p. 6.

Chandler, A. D. (1962). Strategy and structure. MIT Press, Cambridge, p. 14-16.

Durlik, I. (1998). Restrukturyzacja procesów gospodarczych. Reengineering. Teoria i praktyka. Warszawa: Placet.

Gajdzik, B. (2011). Competitiveness of metallurgical enterprises after restructuring in domestic steel industry. HutnikWiadomości Hutnicze, Vol. 78, No. 11, p. 945-952.

Gajdzik, B. (2008). Kodeks nowych wartości w przedsiębiorstwach produkcyjnych. In: M. Duczmal, T. Pokusa (eds.). Ekonomiczno-spoleczne problemy współczesnego zarzqdzania i komunikacji. Seria: Monografie i Opracowania, Opole: Wyższa Szkoła Zarządzania i Administracji, s. 109-119.

Gajdzik, B. (2012). A metallurgical plant after restructuring. Dynamics of changes in domestic metallurgical sector in 1992-2010. Gliwice: Politechnika Śląska. 
Gajdzik, B., Borowik, S. (2008). The safety and hygiene of work in the steel company. Hutnik-Wiadomości Hutnicze, Vol. 75, No. 2, s. 66-70.

Grudzewski, W. M., Hejduk, I. K., Sankowska, A., Wańtuchowicz, M. (2010). Sustainability w biznesie. Warszawa: Poltext, s. 26.

Hurry, Z. D. (1993). Restructuring in the Global Economy. Strategic Management Journal, Vol. 93, No. 14, s. 16.

Ingram, M. (2002). Cele i techniki restrukturyzacji przedsiębiorstw. Katowice: AE, s. 25.

Kamela-Sowińska, A. (1996). Wartość firmy. Warszawa: PWE, s. 32.

Kim, W. C., Mauborgne, R. (2004). Value innovation, Harvard Business Review, Vol. 82, No. 7/8, s. 172-180.

Malara, Z. (2001). Restrukturyzacja organizacyjna przedsiębiorstwa. Wrocław: Politechnika Wrocławska.

Manganelli, R. L., Klein, M. M. (1998). Reengineering. PWE, Warszawa, p. 21-26.

Michalski, M. (2001). Zarzqdzanie przez wartość. Warszawa: WIG-Press.

Nalepka, A. (2006). Restrukturyzacja przedsiębiorstwa. Zarys problematyki. In: M. Rochoń (ed.). Efektywność restrukturyzacji finansowej przedsiębiorstw. Szczecin: Wydawnictwo Walkowska.

Nowak, Z. (2001). Zarządzanie środowiskiem, part 2. Gliwice: Wydawnictwo Politechniki Śląskiej.

Piontek, B. (2002). Rozwój zrównoważony i trwały w miernikach oraz w systemach sprawozdawczości. Bytom: Wyższa Szkoła Ekonomii i Administracji.

Porada-Rochoń, M. (2009). Restrukturyzacja przedsiębiorstw w procesie adaptacji do wspótczesnego otoczenia. Perspektywa międzynarodowa. Warszawa: Difin.

Rappaport, A. (1999). Wartość dla akcjonariuszy. Warszawa: WIG-Press, s. 11.

Raport AMP. (2010). Social responsibility. Dąbrowa Górnicza: AMP, p. 18-19.

Singh, H. (1993). Challenges in Researching Corporate Restructuring. Journal of Management Studies, No. 30, p. 148-150.

Thierry, D. (1995). Restructurations et reconversions. Concepts et methods. Editions L' Harmattan, p. 14.

Wziątek-Staśko, A. (2011). Ethics in the HRM process as a way to the sustainable development of the organization. Journal of Management and Sustainable Development, Vol. 29, No. 2, p. 71-75.

Wziątek-Staśko, A. (2012). Diversity Management - narzędzie skutecznego motywowania pracowników. DIFIN, Warszawa, p. 149.

\section{PLIENO LIEJIMAS LENKIJOS RINKOJE DARNUMO ASPEKTU}

BOŻENA GAJDZIK

Silezijos technologijos universitetas (Lenkija)

\section{Santrauka}

Šiame straipsnyje apibūdinama plieno liejimo rinkos situacija restruktūrizacijos procese, išanalizuoti ir pateikti pagrindiniai įmonės konkurencingumo elementai. Taip pat nagrinëjami organizaciniai pokyčiai plieno liejimo fabrikuose ir jų poveikis darniam vystymuisi. Straipsnyje nagrinėjamos dvi konkrečios plieno liejimo įmonių restruktūrizavimo rūšys: modifikavimas ir vystymas.

PAGRINDINIAI ŽODŽIAI: darnus plieno liejimas, restruktūrizavimas, tobulinimas, darnumas.

JEL KODAI: Q010, Q150 